3. P. Zuiev, R. Zhyvotovskyi, O. Zvieriev, S. Hatsenko, V. Kuprii, O. Nakonechnyi, M. Adamenko, A. Shyshatskyi, Y. Neroznak, V. Velychko. Development of complex methodology of processing heterogeneous data in intelligent decision support systems. 2020, Vol. 4, No. 9 (106), Pp. 14-23. DOI: https://doi.org/10.15587/1729-4061.2020.208554.

4. A. Shyshatskyi, O. Zvieriev, O. Salnikova, Ye. Demchenko, O. Trotsko, Ye. Neroznak. Complex Methods of Processing Different Data in Intellectual Systems for Decision Support System. International Journal of Advanced Trends in Computer Science and Engineering. Vol. 9, No. 4. Pp. 5583-5590 DOI: https://doi.org/10.30534/ijatcse/2020/206942020.

DOI https://doi.org/10.30525/978-9934-26-046-9-4

\title{
INFORMATION-ANALYTICAL SYSTEM OF NATURE PROTECTION TERRITORIES MANAGEMENT
}

\author{
Zagorodnya S. A. \\ Candidate of Technological Sciences, Senior Research \\ Institute of Telecommunications and Global Information Space \\ of the National Academy of Sciences of Ukraine \\ Sheviakina N. A. \\ Ph.D., Senior Research \\ Institute of Telecommunications and Global Information Space \\ of the National Academy of Sciences of Ukraine \\ Radchuk I. V. \\ Ph.D., Senior Research \\ Institute of Telecommunications and Global Information Space \\ of the National Academy of Sciences of Ukraine \\ Kyiv, Ukraine
}

One of the key tasks of environmental management is to create national information system for environmental protection. This system should provide access to environmental information, in particular, it will contribute to the creation of a national system of nature reserve areas and their status. The issue of protected areas monitoring is pressing in any part of our planet. To increase and preserve biological and landscape diversity, it is neces- 
sary to have comprehensive information on the state and dynamics of the research object change which is a certain local ecosystem.

Environmental objects assessment should be carried out on the basis of the entire complex of available information, namely: location data, land use category, borders and total area of nature reserve areas; information from authorized executive bodies in the sphere of creation and preservation of protected areas; organization and previous use of the area; data from area creation design project, nature records materials, monitoring data and special works of settlements and growth of valuable species of fauna and flora; development of infrastructure, transport connection routes including environmental impact aspects [1].

To address the above issues it is reasonable to use a complex of methods for assessing of environmental status of protected areas and forecasting of an anthropogenic impact on the ecosystem. For informational support of decisions making as for implementation of tasks regarding biodiversity loss termination, the formation of an environmental network, nature conservation development it is necessary to create State geoinformation system of environmental objects network.

The main aspect of geoinformation system functioning should be spatially oriented data representation, that is the ability of the system to model environmental situation in a specific natural reserve area by analyzing geographically bound empirical data relating to the environmental status of the area and possible factors of anthropogenic impact inside and outside the selected site as well [2]. Despite active development of information technologies, the issues of nature reserve areas environmental monitoring are paid relatively little attention. During assessment of protected areas as complex ecosystems, the specifics of genetically united, interconnected biocenoses, valuable landscape complexes, and transboundary territories should be taken into account. The involvement of information technologies for the study of nature reserve areas, their morphology and components at the modern scientific and technical level is an important task for addressing the issues related to nature conservation and recreational and economic functions of nature reserves and adjoining territories.

GIS structure for nature reserve fund should be the result of joint development of several functional groups of users - environmental scientists, modeling specialists, specialists in automated control systems, IT specialists. The main functions of environmental GIS of nature reserve areas are:

- Visualization and mapping of environmental assessment results;

- statistical analysis of the results;

- issue of recommendations for adoption of management decisions. 
Recommendations is making by using methods of study of natural objects that are under conservation status and carry the function of natural environment stabilization and namely remote sensing methods, mathematical modeling of anthropogenic load processes and environmental reactions to this process and GIS technologies.

The use of geoinformation technologies will significantly increase the efficiency of decision-making that will increase the effectiveness of environmental management of protected areas. GIS should include tools for obtaining statistics, both in the form of a database and interactive maps as well, convenient simulation tools including input and output tools, further interpretation of simulation results, analysis tools, conclusions and issuance of recommendations for use of system approach methodology by the expert.

It is proved that such a system should be technologically organized as follows:

- input data and indicators, data sources (needs and availability);

- estimated parameters of ecosystems state and anthropogenic load;

- a set of estimated indicators, criteria and scale, algorithms of calculation;

- system of evaluation maps and tables (according to the estimated indicators);

- requirements as for software for workplaces and personnel;

- methodical scheme and operations sequence during monitoring.

For effective decision-making in the sphere of nature reserve areas preservation and environmental safety ensuring, it is necessary to develop a geoinformation system, the core of which should be the environmental and mapping model of the nature reserve area, which reflects current environmental situation and assessment results. On the basis of the above GIS it is necessary to develop a scheme of the state information and analytical system for protected areas management which will function as an environmental decision making support system. Information technologies and systems are based on the GIS technologies and analysis of protected areas space images, for environmental status assessment and changes dynamics within studied ecosystems, as well as for reserve areas ecosystem management tasks solving. The descriptive and analytical part of the geoinformation system of nature reserve area assessment should contain data on:

- geographical location, region surrounding;

- natural resource potential;

- landscape features of relief, soil characteristics and hydrology; 
- climate conditions (temperature regime, precipitation, humidity, wind, etc.);

- materials from scientific research concerning the natural reserve object;

- the environmental situation in the region.

The control system is an open information system, priorities of important environmental public interests, natural ecosystems preservation, reproduction of crisis changes in the state of environment and prevention of emergency ecological situations [3]. Creation and functioning of the control system for integration of environmental information systems covering natural protected areas is based on the following principles:

- consistency of regulatory and organisational and methodical support, compatibility of technical and software support of its components;

- systematic monitoring of environmental state and affecting it anthropogenic objects;

- early obtaining, the complexity of the processing and use of environmental information that is received and stored within the monitoring system;

- the objectivity of primary, analytical and forecast environmental information and the efficiency of its transmission to the state authorities, local self-government bodies, public organizations, mass media, and population.

- patterns that can not be detected by other methods.

GIS integrate not only information resources but also advanced information technologies: database technologies, automated cartography technologies, digital processing technologies for positioning and Earth remote sensing, Web services technologies in open Internet environments, etc. GIS technologies combine traditional operations with databases such as inquiry and statistical analysis with the benefits of full-fledged visualization and geographic (spatial) analysis provided by the map. That is, with the help of GIS, an effective user interaction with distributed information resources containing data on the geographic binding of real objects can be arranged, as it ensures the integration of diverse spatial information and the most natural representation for a person in the form of a map [4]. However, existing methods for representation and analysis of spatial information from small and homogeneous data sources, to which the latest geographic information systems are oriented, require improvement and development of fundamentally new methods of interaction of users with distributed information resources, systems and between themselves in the process of 
using digital geographic data, the volume of which is constantly increasing, and types, formats and sources of income are diversified.

\title{
References:
}

1. Korchenko O., Pohrebennyk V., Gancarczyk J., Sheviakina N., Zagorodnia S. Use of modern information technologies for and management of nature reserve areas/ International multidisciplinary scientific geoconference SGEM 2019. Albena, Bulgaria. 2019. P. 697-703.

2. Trofymchuk O., Yakovliev Y., Klymenko V., Anpilova Y. Geomodeling and monitoring of pollution of waters and soils by the earth remote sensing. International Multidisciplinary Scientific GeoConference SGEM. 2019. № 1-4. Pp 197-204.

3. Lukianova, V., Trofymchuk, O., Anpilova, Y. Environmental safety of motor transport enterprises within the urban areas. Journal of Ecological Engineering. 2020. Vol. 21(4). Pp 231-236.

4. Trofymchuk O., Zahorodnya S., Sheviakina N., Radchuk I., Tomchenko O. Remote Sensing Monitoring of Biotopes Distribution within Nature Reserve Area. Journal of Environmental Research, Engineering and Management. 2020. Vol. 76. No. 3. Pp. 109-120.

DOI https://doi.org/10.30525/978-9934-26-046-9-5

\section{ОБГРУНТУВАННЯ НАПРЯМКІВ \\ ЗАСТОСУВАННЯ ТЕХНОЛОГІЙ ШТУЧНОГО ІНТЕЛЕКТУ У ВІЙСЬКОВІЙ КІБЕРНЕТИЦІ}

\author{
Івахненко Т. 0. \\ кандидат технічних наук, \\ провідний науковий співробітник науково-дослідного відділу \\ Центральний науково-дослідний інститут озброєння \\ та військової техніки Збройних Сил Украӥни \\ м. Київ, Украӥна
}

Вступ. Зразки озброєння та військової техніки (ОВТ), побудовані відповідно до традиційних принципів дії та фізичної (поелементної) побудови, невпинно приближуються до своїх граничних можливостей, що зумовлює необхідність пошуку та застосування нетрадиційних підходів при подальшому розвитку ОВТ та інших прин- 